David Wilkie 



\section{David Wilkie}

\section{The People's Painter}

Nicholas Tromans

Edinburgh University Press 
(C) Nicholas Tromans, 2007

Edinburgh University Press Ltd

22 George Square, Edinburgh

Typeset in Miller Text

by Servis Filmsetting Ltd, Manchester, and

printed and bound in Great Britain by

Cromwell Press, Trowbridge, Wilts

A CIP record for this book is available from the British Library

ISBN 9780748625208 (hardback)

The right of Nicholas Tromans

to be identified as author of this work

has been asserted in accordance with

the Copyright, Designs and Patents Act 1988. 